\title{
Ecclesiology and theological education: A South African reformed perspective
}

C J Wethmar

(UP)

\begin{abstract}
Ecclesiology and theological education: A South African reformed perspective
\end{abstract}

The church is one of the primary contexts in which theology is done. In the South African theology education debate the implications which this context has for the nature of theological education has not yet been adequately described. This article therefore intends dealing with this issue. The well known four attributes of the church are used as indicators of the nature of theological education which results in confessionality, spirituality, ecumenicity and hermeneutics being identified as its main dimensions.

\section{INTRODUCTION}

It is no exaggeration to say that in the world of theological education the past decade globally was one characterized by turmoil. In most countries with a long Christian heritage intensive and extensive discussions on the nature and scope of theological education took place. In a variety of circumstances the same startling discovery was made, namely either that the guiding principle or basic idea behind theological education had become blurred or even that churches whose prospective ministers were being trained in theological programmes had become unsure about their own identity and orientation'. The extraordinary extent of the discussion just mentioned is probably due to the fact that issues related to theological education are particularly sensitive to and therefore register the social, cultural and political forces that at present are brought to bear on Christian churches worldwide.

As is the case elsewhere South Africa was also involved in this intensive debate on theological education and ministerial formation ${ }^{2}$. The influence of the international discussion on the local one can easily be discerned. Frequent references to Tracy's three publics, Kelsey's Athens and Berlin models, the Dutch idea of duplex ordo and the German notion of theological competence bear eloquent witness to this fact ${ }^{3}$. In spite of all 
this, and understandably so, the South African debate is characterized by its own particular issues and emphases. These issues and emphases are to a large extent related to the new political dispensation that developed in South Africa. A new political dispensation invariably brings with it a new educational policy which is at this moment in a process of finalization. At this stage it is not yet entirely clear in which manner theological education will be affected by the implementation of this policy. What is clear however is the fact that Christian theology will no longer retain its position at state-funded universities for traditional religious or ideological reasons but it will have to justify its presence in academic and moral terms. And this I think can be done.

This will furthermore require a more explicit involvement of the churches. Already a number of them have started reaching out to each other to consider co-operation in order to be able to provide or to gain access to suitable tertiary facilities for the training of ministers. Most churches are confronted by serious financial problems. In many cases a fulltime paid ministry seems difficult to maintain. This kind of problem will definitely influence the future structure of theological education.

Another important factor which will have to be taken into account is the fact that the Afro-centric dimension has not yet come into its own on the overall cultural scene in South Africa in general and on the theological scene in particular ${ }^{4}$. Both the Afro-African and the Euro-African traditions bring with them their own opportunities and challenges for an authentic rendering of the Christian faith. Hopefully a thoroughgoing dialogue between these traditions will prove to be beneficial to each other ${ }^{5}$.

It is impossible to deal with all the relevant aspects of such a complicated issue as theological education in a single paper. For this reason I intend mainly dealing with one aspect in this regard and that is the influence of ecclesiology on theological education. This is one dimension of the recent South African debate which has not yet received the attention it deserves. One does from time to time come across statements that theological education should be ecclesiastical in nature without however simultaneously receiving an adequate explanation why that should be the case. One gets the impression that those institutions where churches, either in co-operation with university faculties or in independent seminaries, provide training of candidates for the ordained ministry takes the ecclesiastical nature of their activities for granted.

A striking element that one does however occasionally come across in the South African debate is what one may call an anti-church sentiment against the presence of confessional theological education in the context of 
a state-funded university. This position was given its thusfar most poignant expression in the following complaint: "The problem with confessional training is that it may obviate academic freedom and an unbiased study of theology. Theological training is subjected to external power based surveillance and control. The insistence of churches for a strict professional and confessional training implies a closure of the theological mind" 6 . One cannot but get the impression that this complaint sees the basic function of the church in relation to theology as that of exercising restrictive control. It is therefore understandable that the complaint just mentioned is followed by the expression of the hope that "state-funded theological seminaries will experience a slightly slacker grip of churches on theological training in future", so as to be "free from clerical hierarchical domination"?. In developing this position further the perception is created that the confession is the mechanism with which this control is exercised. For this reason church theology is constantly described as "confessionaly bound" or as "inimical to an open theology", and therefore regarded as "parochial and methodologically limited" 8 . Over against this position a context which is non-denominational, ecumenical and free should be preferred. Examples of approaches similar to this one can easily be found in the international theological education debate but they need not occupy our attention here.

As ecclesiology is as yet not a major emphasis in the local theology education debate it would be worth while to attempt a contribution to this debate from this vantage point. That means starting with the question as to the nature and attributes of the church. This of course can be done and is being done in a variety of ways. Especially popular at the moment is taking a socio-cultural approach and this definitely has its advantages ${ }^{9}$. In dealing with the question what implications ecclesiology has for the structure of theological education I prefer however to take a more fundamental theological approach.

\section{THE NATURE AND ATTRIBUTES OF THE CHURCH}

In an attempt to ascertain the nature of the church one should keep in mind that the church is involved in a history and therefore does not always and everywhere look the same. To gain a proper understanding of this history one should distinguish between the essence of the church and the historical forms in which this essence finds expression ${ }^{10}$. According to the Reformed approach in ecclesiology this essence is given in the church being the church of the Word.

Essence and historical form should neither be separated nor should it be equated ${ }^{11}$. The first should not be done because that leads to speculation 
on an abstract notion of the church without due attention to concrete issues in church life. The second should be avoided because that brings about a situation in which there is no criterion according to which the validity of a particular historical form of the church can be measured.

No single historical manifestation of the church reflects its essence perfectly and exhaustively. This insight is reflected by the well known Reformed expression of ecclesia reformata semper reformanda. On the other hand however the essence of the church is never to be found in the abstract but only in a particular historical form which always has to be understood in the light of and with reference to its essence.

The implication of the Reformed position of seeing the essence of the church in its being the church of the Word, is that the church does not constitute a societal structure amidst other similar structures but that it has a unique origin. This fact is emphasized when the Apostle's Creed and the Reformed confessions regard the church as an object of faith. The church cannot be properly judged from outside, from the viewpoint of a neutral observer but only from a position of faith ${ }^{12}$. This is the case because the church has its origin in the triune God.

This does not imply a deification of the church. Christians do not believe in the church as they believe in God. But only because of their faith in God do they also regard the church as an object of faith and as having its origin in God'13.

This point is further emphasized when one takes into account that in the Apostle's Creed the church is mentioned in its third article dealing with the Holy Spirit. The church is therefore spoken of as a consequence of the reference to the Holy Spirit. This is indicative of a profound relationship between the Holy Spirit and the church. Church history provides ample evidence that neglect of this relationship gives rise to positions towards which the Reformed Confessions traditionally took on a polemical position, namely the Roman Catholic and Anabaptist positions ${ }^{14}$. The former was said to neglect the work of the Holy Spirit in favour of institutional structures while the latter was regarded as disregarding church structures in favour of a spiritualistic enthusiasm ${ }^{15}$.

In opposition to the enthusiast position the Reformed confessions maintained that the Holy Spirit is not given its due recognition if one is not willing to get involved in the concrete issues of day by day church life while they on the other hand expressed the conviction that the church is actively and dynamically gathered by the Son of God, through the Spirit and his Word, from the beginning to the end of the world, and from among the whole human race as a congregation chosen for eternal life ${ }^{16}$. 
This dynamic dimension in the origin of the church is emphasized when the Belgic Confession in the original French version and in the Latin translation uses two words to give expression to it namely congrégation (Latin: congregatio) on the one hand and assemblee (Latin: coetus) on the other ${ }^{17}$. Coetus denotes the idea of people gathering together while congregatio, in which the notion of flock (grex) features prominently, emphasized the fact that Christ as the good Shepherd brings together his sheep (John 10:3 and 4).

This idea of the mysterious origin of the church reaches its apex in Reformed thinking with the emphasis on divine election as the final background of the church's existence. Divine election on the other hand does not function outside the context of the preaching of the Word of the cross through which faith and the forgiveness of sins are brought about. For this reason Reformed thinking does not hesitate to maintain the early church maxim of extra ecclesiam nulla salus ${ }^{18}$.

This line of argument clearly indicates that the church is a reality which operates within a soteriological context and not within the sphere of the doctrine of creation ${ }^{19}$. No other social structure is linked to the salvation brought about by Christ in the same fundamental manner as the church is. Within all social structures only the church is called people of God, body of Christ and the temple of the Holy Spirit. The church is a new creation and a new humanity.

The unique nature of the church can further be elucidated by describing its relationship to the eschatological reality of the reign of $\operatorname{God}^{20}$. The church and the reign of God should neither be equated nor should they be totally divorced from each other. The relationship between the church and the reign of God is that of service. The church has to proclaim the reign of God. And the life and service of the church should be a preliminary reflection of God's intentions with this world.

In the political struggle that had been characteristic of the South African scene on its way to a new political dispensation the church was faced by the challenge to avoid either being absorbed by civil society in terms of an apartheid theology on the one hand or by being converted into a people's church in an anti-apartheid theology on the other. In the aftermath of the controversies just mentioned the church should steer clear of concentrating on either a cerebral doctrinal orthodoxy on the one hand or on an exclusively political praxis on the other. The church should serve the reign of God and the comprehensive salvation of mankind by a doxological existence that combines and thus transcends the sterile dialectic of orthodoxy and orthopraxis. 
In an attempt to gain a proper grasp on the nature of the church and its relevance for understanding the structures of theological education one should not neglect those dimensions of the church which since the fourth century have come to be known as its attributes. It should furthermore be kept in mind that these attributes are not to be seen as four isolated qualifications. They should rather be regarded as four dimensions of the same reality and therefore closely related to each other. If one is neglected all the other suffer the same fate ${ }^{21}$.

In referring to the unity, holiness, catholicity and apostolicity as the attributes of the church however, one should be aware that the church does not automatically conform to these ideals. Only in a relationship of faith to the church are they recognised as dimensions fundamental to its life and goals that should be pursued with determination and dedication.

This is the reason why the idea of the attributes of the church was combined in Reformed thinking with the notion of the true marks of the church. These are well known to be the pure proclamation of the gospel, pure administration of the sacraments and the exercise of church discipline. The basic intention of the identification of these marks was to ensure that the church lives in the guiding presence of the living Christ. This guidance Christ gives through his living Word. These marks of the true church are the criteria for ascertaining the authenticity of being the church while the four attributes describe the manner in which this takes place.

In an attempt to ascertain the relevance of ecclesiology for theological education it is important to briefly attend to exactly what these attributes entail. As we have seen the first of these attributes is unity. The basic motivation for the unity of the church is not found in the church members themselves but in the triune God who calls the church into existence. The unity of the church is therefore determined by the fact that Christians believe in the same God and therefore share the same confession of faith.

The holiness of the church is not based in itseif but in that which it receives from God namely the self-giving of Jesus Christ and the gift of the Holy Spirit. A church that lives from the holiness that has been given to it is called to live a life of holiness. It is called to be what it already is in Jesus Christ.

The catholicity of the church is indicative of its comprehensiveness. According to Reformed thinking the church exists throughout history and in and through the whole world and all its cultures. Catholicity therefore has a historical, geographical and cultural dimension 22 . These three dimensions together constitute what may be called quantitative catholicity. But 
this quantitative catholicity on its own does not yet make the church truly catholic. Catholicity therefore, in addition, also has a qualitative dimension which refers to the full depth and comprehensiveness of the gospel message and of the salvation given in Christ and through the Holy Spirit. Quantitative catholicity can only be attained if it is based on qualitative catholicity ${ }^{23}$. And the latter of course, is only possible when a church perseveres in a living personal relationship with Christ and his Holy Spirit.

It has already been emphasized that the attributes of the church are interrelated. This becomes especially evident when one refers to the apostolicity of the church. In the apostolicity implies that the one, holy and catholic church is based on the original witness to Jesus Christ. This does not necessarily mean the static maintenance of traditional formulae but rather the living and dynamic validity of the original apostolic witness to Christ's presence and mission in the world. In concrete terms this implies acceptance of the living authority of Scripture and its reflection in the confession of the church. In the process in which this comes about, theology plays an important role. And this confronts us with the question what exactly the relationship between church and theology is.

\section{THE RELATIONSHIP BETWEEN CHURCH AND THEO- LOGY}

The controversial character which the relationship between church and theology at present often has, has already been highlighted in the introductory remarks to this paper. This relationship has however not always been of such a strained nature. From the rise of early church orthodoxy up to the period of post Reformation orthodoxy the close relationship between church and theology was taken for granted to such an extent that it was not even discussed ${ }^{24}$. Only since the Enlightenment of the eighteenth century did a fundamental theological discussion on this issue start which, in the liberal theology of the nineteenth century, even led to the propagation of a non-church theology. The dialectical theology of the early twentieth century reacted to this with a deliberate programme of church theology in which Karl Barth's Church Dogmatics played an important role. The discussion on the relationship between church and theology is one which has not yet been concluded ${ }^{2}$. But the technical details of this continuing discussion, however fascinating it is, need not occupy us further in the present context.

In general however one could say that in Reformed circles there has traditionally been appreciation for the close relationship between church 
and theology. The church and its faith has always been regarded as the presupposition of theology. The basic task of theology was seen as having to systematically explain and critically evaluate the church's faith in terms of Holy Scripture. This kind of theology has its origin in the church and its main aim is serving the church ${ }^{26}$.

For the church on the other hand this means that its dealing with Scripture mainly has a theological character. And as this theology mainly consists of interpreting Scripture, it basically has a hermeneutical character in contradistinction to scholastic theology which is characterized by a metaphysical-speculative approach ${ }^{27}$. This hermeneutical theology is part of the process in which the Word is proclaimed and therefore part of the process in which the church is the church of the Word. Theology is therefore seen not as a luxury but as a necessity for the life of the church. And for this reason theological formation of ministers was a matter of priority from the start of the Reformation. Ministers were expected to perform their ministry of preaching, teaching and pastoral work in a theologically competent manner. Even of elders the expectation was harboured that they should participate in church meetings and decision making in a theologically knowledgeable way. All of this of course imply that it is not possible to make a clear distinction between professional theology on the one hand and non-academic church theology on the other ${ }^{28}$. It is obvious that in the Reformed tradition theologians played a far more important role in church life than would be conceivable, for example, in a Roman Catholic context.

As indicated above the fairly idyllic situation just described had been complicated by the European Enlightenment. While the church faced the challenge to adequately respond to the incisive questions set by the modern era, theologians often became more interested to conform to the criteria of the newly developed historical critical science than to serve the church. This led to an estrangement between theology and the church. In some cases theology was replaced in university faculties by a neutral and merely descriptive science of religion. This gave rise to the development of independent church seminaries where theology could be studied in conformity with the confessions of the churches involved. In this manner the initial unity between church and theology broke down ${ }^{29}$.

This process did not develop in South Africa in the same time or at the same pace as in Europe. Until quite recently most churches of the Reformed tradition in South Africa did not yet experience the full impact of Enlightenment thinking. The result was that to a certain extent a very positive relationship between church and theology obtained. This was reflected in the Dutch Reformed Church, for example, by the fact that professional 
theologians were several times elected to serve in executive church positions $^{30}$. One should however also take note of the fact that in some contexts in South Africa another kind of estrangement between church and theology than that which has been described thus far, took place. Liberation Theology is a case in point. This kind of theology mainly developed in a political environment and was not really at home within traditional denominational contexts $^{31}$.

It is to be expected that the developments of the past decade will expose South African society to the full impact of modernization. What the effect of this on the church in South Africa will be is not yet clear. In such a situation of transition the danger always exists that theology in its attempt to relate the Christian message to present-day thinking may exceed the gospel of Christ. The opposite danger is that theology can be restricted by the church to such an extent that it loses its vital critical function.

It is therefore of the utmost importance that a responsible relationship between church and theology be maintained. This should be one in which they deliberately cultivate their innate relationship. This should be done in such a manner that the important mutual element of critical solidarity towards each other is not neglected. The church should challenge theology to deal with Scripture conscientiously and accurately while theology should conversely demand that the institutions, attitudes and decisions of the church should constantly expose itself to the living authority of Scripture ${ }^{32}$.

\section{DIMENSIONS OF THEOLOGICAL EDUCATION}

It has already been emphasized that according to Reformed thinking theology and theological education plays an important role in the life of the church. It would exceed the limits of this paper to extensively deal with concrete issues of methodology or curriculum in ministerial formation. What is vital to our topic however is to give a few indications of how the ecclesiological insights developed so far influence and shape theological education.

One could do so by pointing to the basic tenor of Reformed ecclesiology, according to which the church is portrayed as the church of the Word, as fundamental idea governing theological education. One could therefore say that the basic motive of theological education in a Reformed context is that theology should serve the church in being the church of the Word to the honour of God and the wellbeing of mankind.

One could furthermore refer to the attributes of the church as indicative of what the basic dimensions of theological education should be. 


\subsection{Confessional}

The idea of the unity of the church may be taken to imply that theological education should preferably be confessional in nature. It has been indicated earlier on that the unity of the church is reflected in believers being able to express their faith in a common confession. It has furthermore been established that the faith of the church is the presupposition of theology. All this add up to the proposition that theological education should preferably have a confessional character. This position seems to run counter to the anticonfessional strain in the South African theology education debate which I referred to in the beginning. But, to my mind, one should enquire whether this anti-confessional stance is not based on a misunderstanding of what the relationship between church and theology or between a confession and theology entail. Is it really feasible to restrict the function of the church and its confession to that of exercising control which hampers theology in its freedom? Is it not true that the church and its confession constitutes a far more comprehensive context of faith which, inter alia, also contains a doxological and liturgical dimension? And are these dimensions not an integral part of and an indispensable presupposition for knowing and honouring God truly? Seen in this way a confession is not a restrictive but a liberating truth which does not hamper but encourage theology ${ }^{33}$.

\subsection{Spiritual}

Describing the aim of theological education with the epithet "spiritual" may be open to misunderstanding. This does not mean that this term cannot be used in this connection at all. It would, on the contrary, for example, be possible to do so in the context of a church with a strong sacramental conception of ministry as priesthood. In this case theological education would be regarded as the formation of priestly character intended to prepare candidates for a life as extraordinary sacramental and spiritual persons ${ }^{34}$.

It is, however, also possible to regard spirituality as a dimension of theological education from a Reformed point of view ${ }^{35}$. In Protestant thinking the holiness of the church implies that it should live by the holiness it receives in Christ and through the Holy Spirit. The Spirit establishes the relationship between the church and God and this relationship is reflected in Christian spirituality. One should take note that the Belgic Confession's portrayal of the well known marks of the true church is complemented by the true marks of a believer ${ }^{36}$. The description of these marks can be 
regarded as a lucid description of Reformed spirituality. These marks, in summary, are: receiving Christ the only Saviour, avoiding sin, following after righteousness, loving the true God and one's neighbour. This brief description suffices to indicate that Reformed spirituality combines mystical depth and moral activity. Theological education in the Reformed tradition should serve both these ideals. The emphasis on spirituality does not only have a formative effect on the person of the theological student but it also has a unifying and concentrating effect on theological teaching and research. It serves as a mechanism which provides a clear focus of all the activities of a theological institution. Specialization in teaching and research is necessary from an academic point of view but it may never lead to any discipline or scholar withdrawing from pursuing the common spiritual aims of religious and moral commitment that form a part of ministerial formation. This point serves as an indication of how closely the dimensions of spirituality and confessionality are interrelated. The classical formula of lex orandi lex credendi is of relevance also for the structure of theological education.

\subsection{Ecumenical}

Related to the catholicity of the church, the ecumenical character of theological education should be emphasized. The ecumenical nature of theological education is rooted in the ecumenical nature of theology as such.

Earlier on we indicated that, as far as the catholicity of the church is concerned, one should distinguish between quantitative and qualitative catholicity, the former being based on the latter. The qualitative catholicity can only be approached through the quantitative catholicity. The breadth and length and height and depth of Christ's love can only be comprehended together with all God's people (Ephesians 3:18). Theological truth is closely related to the catholicity of the church. On the other hand catholicity is dependent on the ultimate eschatological truth being envisaged and constantly aimed at. This truth, however, cannot in this dispensation be found in a final consensus. It represents that fullness of truth which belongs to God alone and in which his creatures will share only at the end of the age ${ }^{37}$. In the meantime the church is on its way to this truth. Our insights at present, however important and decisive, are only provisional approximations of the final truth and therefore open to correction. This correction takes place in a dialectical process of dialogue between churches in which orthodoxy is established as a dialogical orthodoxy ${ }^{38}$. 
In this process confessionality and ecumenicity both play a vital role and the institutionalization of theological education should take cognisance of both. Before asking the question what exactly the implications of this statement are I would first like to attend to the fourth dimension of theological education which corresponds to the fourth attribute of the church, namely its apostolicity.

\subsection{Hermeneutical}

This fourth dimension is its hermeneutical nature. The dialogical development of theological truth in which opposing truth claims periodically confront each other is dependent on a criterion in terms of which these claims can be evaluated. In Protestant thinking Holy Scripture constitutes this criterion. This implies that theology is basically a hermeneutical discipline of which the primary aim is a historical, systematic and practical interpretation of the Biblical text as basic source and permanent foundation of Christian faith in God. The basic challenge that theology has to meet in this process is to maintain the identity of the Biblical message in ever changing contexts, in such a manner that this message at the same time retains its relevance for those who receive it. This is the classic challenge of nove dicere sed non nova that Vincent of Lérins already formulated in the fifth century and which is still as valid as ever ${ }^{39}$. This is indicative of the fact that the hermeneutical issue is a basic dimension in the theological endeavour and should receive full attention in any programme of theological education.

\section{THE INSTITUTIONALIZATION OF THEOLOGICAL EDU- CATION}

Having identified some of the basic dimensions that should determine theological education we have to attend to one last question and that is what implications our ecclesiological considerations have for the institutional organization of theological education.

We have already seen that theology is not something that has to be imposed on the life of faith. It rather reflects an intellectual hunger rooted in faith itself as Anselm of Canterbury's definition of theology as fides quaerens intellectum suggest ${ }^{40}$. In the Reformed tradition theology mainly adopts an hermeneutical approach, as its main task is to assist the church in being the church of the Word. As the Word, with its reference to the transcendent origin of the existence and wellbeing of mankind, has to be 
proclaimed in varying contexts, expert knowledge of the form and content of this message and of the contexts into which it has to be communicated, has to be obtained. This presents an academic task of the highest order. Dealing with this daunting task in a responsible manner requires very definite measures of an institutional nature. In the period of the early church this challenge was met by catechetical schools. During the early Middle Ages this was done by monastic schools and from the High Middle Ages onwards by universities ${ }^{41}$. And in the early modern times, when the universities became secularized and nationalized independent church seminaries and academies were developed for this purpose.

It has been indicated earlier on that no sharp opposition can be drawn between theology done at a university and that done in other forums. This leads to the conclusion that whether theology is taught in a university faculty or in a seminary is not a matter of principle but in most cases an issue based on political, cultural or economic circumstances ${ }^{42}$.

In comparing the various forms of institutionalization with each other, however, a number of important reasons for locating theological education at a university faculty can be mentioned. In doing so one should realize that this is not a position that has always been popular to everyone. In the early fifteenth century, for example, John Wycliffe rather vehemently took the opposite position when he wrote: "Universities, with their programmes of study, their degrees, and their professorships, are products of vain heathenism; they are as much good to the church as the devil is" 43 . The subsequent rejection of this position by the official church can be taken as evidence of the appreciation which many churches throughout the centuries had for universities and their theological faculties.

In taking this position the church emphasizes the relevance which the Christian faith and Christian living has for all spheres of reality and life of which the highest level of knowledge is cultivated in a university context. By withdrawing theology from the university the church would contribute to an already developing marginalization of the church and the Christian faith.

Conversely one could say that it is important to the state that a factor of such historical and cultural influence in society as Christianity should not only be studied academically but should also be granted the opportunity to give account of itself on the highest level of academic excellence. In addition to this it is imperative that church officials should be able to perform their professional tasks with the highest degree of competence. To enable them to do so they should have access to the best knowledge available in society. Normally a university is the institution where this is possible. 
It is furthermore imperative that theology in order to fulfill its task in the church should have a certain degree of freedom over against the official church. If it is to serve the church in being the church of the Word it should also serve the critical function of the Word over against the church ${ }^{44}$. The university is traditionally well suited to provide a context for the exercise of this freedom. In a university knowledge is pursued for its own sake, alternative interpretations are explored and axioms and propositions are re-examined.

Keeping in mind that we earlier on defended the position that theological education should preferably be confessional in nature, the question arises whether confessional theology can be done in a university context with its ideal of academic freedom. This question will only be answered in the negative by someone who equates confessionality with legalism. But in a Reformed environment a confession should be seen as the way in which Holy Scripture exercises its authority in a particular historical context. It is a dynamic, relational and Spiritual event that rather enables than restricts ${ }^{45}$. The Reformed tradition with its approach of always being reformed by die living Word and Spirit of God has no problem in keeping commitment and exploration together. Just as conviction and openmindedness can be combined in the same person ${ }^{46}$.

But if one can be convinced that confessionality and freedom should not exclude each other, what about confessionality and ecumenicity? The anti-church complaint with which we started seems to see these two dimensions of theological education in opposition to one another. True confessionality however does have an ecumenical urge in it. It should therefore be possible to combine both dimensions with each other. The best way this can be done in structuring a theological faculty is by the development of federal faculties. This could serve the purpose of didactic responsibility in providing the opportunity to students to develop their own identity of faith while at the same time being willing to serve the rest of the Christian world with the peculiar and particular insights which are represented by the tradition in which one finds oneself.

\section{NOTES:}

1 T W Gillespie, "What is theological about theological education?", The Princeton Seminary Bulletin 14/1 (1993), 59. See also B G Wheeler, "Critical junctures: Theological education confronts its futures", Annals of the American Academy of Political and Social Science 527 (1993), 84-96.

2 P J Robinson \& D J Smit, "What makes theological education "theological'? A South African story on the integrity of theological education", Skrif en Kerk 
17/2 (1996), 405-419. See also H P Müller, "Tertiary academia of religion in South Africa: some statistical perspectives", Scriptura 53 (1995), 125-140.

D Tracy, The analogical imagination. Christian theology and the culture of pluralism, London 1981, 3-46; D H Kelsey, Between Athens and Berlin. The theological education debate, Grand Rapids, 1993; H M Vroom, "Staatsvakken en kerkelijke vakken aan openbare universiteiten", Skrif en.Kerk 18/1 (1997), 210-231; W Hassiepen \& E Herms (Hrsg.), Grundlagen der theologischen Ausbildung und Fortbildung im Gespräch. Die Diskussion über die Grundsätze für die Ausbildung und Fortbildung der Pfarrer und Pfarrerinnen der Gliedkirchen der EKD. Dokumentation und Ertrage 1988-1993, Stuttgart 1993.

$4 \mathrm{C} \mathrm{du}$ Toit, "Some remarks in the dialogue on the future of theological education in South Africa", Religion and theology 2/1 (1995), 41.

5 C J Wethmar, “Teologie en samelewing”, in: H M Kuitert et al (reds), Cultuur als partner van de theologie, Kampen 1990, 35.

6 Du Toit, op cit, 46.

7 Du Toit, op cit, 46-47.

8 Du Toit, op cit, 38-40.

9 D J Smit, "Oor die kerk as unieke samelewingsverband", Tydskrif vir Geesteswetenskappe 36/2 (1996), 119-129 and Idem, "Oor die unieke openbare rol van die kerk", Tydskrif vir Geesteswetenskappe 36/3 (1996), 190-204.

10 H Küng, The Church, London 1968, 3-24.

11 Küng, op cit, 5.

12 Küng, op cit, 30.

13 J M Lochman, Das Glaubensbekenntnis. Grundriss der Dogmatik im Anschluss an das Credo, Gütersloh 1982, 162.

14 A D R Polman, Onze Nederlandsche Geloofsbelijdenis III, Franeker 1939, 293.

15 C J Wethmar, "Die ekumeniese roeping van die kerk in die lig van die Gereformeerde belydenisskrifte”, in: D Crafford \& G Gous (reds), Een liggaam - baie lede. Die kerk se ekumeniese roeping wêreldwyd en in Suid-Afrika, Pretoria 1993, 38.

16 Heidelberg Catechism 20:53.

17 Wethmar, op cit, 1993, 39.

18 Confessio Belgica, Art 28.

19 W D Jonker, "Die unieke karakter van die kerk, In die Skriflig 11/43 (1997), 5. See also $J$ H van Wyk, "W D Jonker as ekklesioloog", in: P F Theron en J Kinghom (reds), Koninkryk, kerk en kosmos, Bloemfontein 1989, 74-96.

20 Jonker, op cit, 1977, 7.

21 C J Wethmar, Ekumenisiteit in dogmatologiese perspektief, in: op cit, 1993, 45.

22 J Faber, "The catholicity of the Belgic Confession", in: Idem, Essays in Reformed Doctrine, Neerlandia 1990, 79.

23 J Faber, "The catholic character of the church", in: Idem, op cit, 86.

24 G Ebeling, "Die theologische Verantwortung und ihre institutionelle Wahrnehmung", Zeitschrift für Evangelisches Kirchenrecht 31(1986), 4.

25 H M Kuitert, "Kerk en theologie: onheelbare tweespalt?", in: H M Kuitert, J Veenhof, H M Vroom (reds), Cultuur als partner van de theologie, Kampen 1990, 109-124. 
26 W D Jonker, “Die verhouding tussen kerk en teolgie”, in: P B van der Watt (red), Kerk-teologie-fakulteit, Pretoria 1988, 1-14.

27 Jonker, op cit, 3.

28 Ebeling, op cit, 23.

29 Jonker, op cit, $1988,9$.

30 Jonker, op cit, 1988, 10. See also D J Smit, “Reformed Theology in South Africa: a story of many stories”, Acta Theologica 12/1 (1992), 88-110.

31 Wethmar, op cit, $1990,40$.

32 K Karner, Einführung in die Theologie, Berlin 1957, 97-107.

33 C J Wethmar, Dogma en verstaanshorison, Amsterdam 1977, 100. See also J Drumm, Doxologie und Dogma. Die Bedeutung der Doxologie für die Wiedergewinnung theologischer Rede in der evangelischen Theologie, Paderborn 1991.

34 D J Bosch, "The nature of theological education", Journal of Theology for Southem Africa 19/1 (1991), 8.

35 A van de Beek, "Spiritualiteit - een must voor theologen?", Gereformeerd Theologisch Tijdschrift 96/1 (1996), 3-10.

36 Confessio Belgica, art 29.

37 J Macquarrie, Christian unity and Christian diversity, London 1975, 34.

38 W Kasper, Einfiuhrung in den Glauben. Mainz 1975, 131-133.

39 H W Rossouw, Klaarheid en interpretasie, Amsterdam 1963, 45.

40 T W Ogletree, "From where I sit: rethinking the mission of the Divinity School", Spectrum 9 (1991), 2.

41 G Ebeling, "The Bible as document of the university", in: H D Betz (ed), The Bible as a document of the university, Chicago 1981, 8 .

42 A Dulles, The craft of theology, New York 1995, 150.

43 Dulles, op cit, 149.

44 Karner, op cit, 107.

45 This position is described in C J Wethmar, Dogma en verstaanshorison, Amsterdam 1977.

46 C H Massa, "Confessional churches and their theological institutions", The Princeton Seminary Bulletin 12/3 (1991), 308. 